\title{
Pengaruh Edukasi dengan Media Linzi terhadap Sikap dan Kinerja Kader dalam Memantau Status Gizi Balita
}

\author{
$\frac{\text { Novita Ika Wardani }{ }^{1} \text {, Listyaning Eko Martanti }{ }^{2} \text {, Teguh Wahyudi }{ }^{3}}{1,2,3 \text { Poltekkes Kemenkes Semarang }}$ \\ Corresponding author: Novita Ika Wardani \\ E-mail: novitaika0@gmail.com
}

Received: February 20 ${ }^{\text {th }}, 2019$; Revised: March $18^{\text {th }}, 2019$; Accepted: April $11^{\text {th }}, 2019$

\begin{abstract}
Child nutrition problems can be handled from the start through the activation of the posyandu. The first screening was conducted at the posyandu by comparing body weight with age. Each cadre has a different attitude and performance in implementing posyandu. The use of assistive devices can influence the attitude and performance of cadres. The aim is to determine the effect of LINZI media on cadres' attitudes and performance. The sample used 25 treatment groups and 25 control groups. The attitude with paired t test showed that in the control group there was a difference between the pre test and post test $\mathrm{p}=$ $0.042(\mathrm{p}<0.05)$ and the treatment group $\mathrm{p}=0.04(\mathrm{P}<0.05)$. The performance of paired t test showed that in the control group there was a difference between before and after $\mathrm{p}=0.001(\mathrm{p}<0.05)$ and $\mathrm{p}=0.000(\mathrm{P}$ $<0.05)$ in the treatment group. There is the influence of LINZI media education on cadre attitudes with an average score of 33.08 treatment attitudes greater than controls 32.96. There is the influence of LINZI media education on the performance of cadres with an average performance score of 26.16 greater than the control 24.84. Cadres can use LINZI media for early screening of toddlers' nutritional status that is more interesting and easy to use.
\end{abstract}

Keyword: LINZI media; cadre attitude; cadre performance; toddler growth and development

\section{Pendahuluan}

Salah satu indikator kesehatan yang dinilai keberhasilan pencapaiannya dalam SDGs adalah status gizi balita. Status gizi penting karena salah satu faktor risiko terjadinya kesakitan dan kematian. Jumlah balita dengan gizi buruk (BB/TB) Provinsi Jawa Tengah Tahun 2016 sebesar 1.074 kasus dimana Kabupaten Blora urutan ke delapan dengan 50 kasus. Pendataan gizi buruk di Jawa Tengah didasarkan pada 2 kategori yaitu dengan indikator membandingkan berat badan dengan umur $(\mathrm{BB} / \mathrm{U})$ dan kategori kedua adalah membandingkan berat badan dengan tinggi badan (BB/TB). Skrining pertama dilakukan di posyandu dengan membandingkan berat badan dengan umur melalui kegiatan penimbangan, jika ditemukan balita yang berada di bawah garis merah (BGM) atau dua kali tidak naik (2T), maka dilakukan konfirmasi status gizi dengan menggunakan indikator berat badan menurut tinggi badan (Dinkes Jawa Tengah, 2015).

Peranan kader sangat penting karena kader bertanggung jawab dalam pelaksanaan program posyandu. Bila kader tidak aktif maka pelaksanaan posyandu akan menjadi tidak lancar dan akibatnya status gizi bayi atau BALITA (Bawah Lima Tahun) tidak dapat dideteksi secara dini dengan jelas. Hal ini secara langsung akan mempengaruhi tingkat keberhasilan program posyandu khususnya dalam pemantauan tumbuh kembang balita. Pada tahun 2007, lebih kurang 250.000 posyandu di Indonesia hanya $40 \%$ yang masih aktif dan diperkirakan hanya $43 \%$ anak balita yang terpantau status kesehatannya. Hal ini menunjukan bahwa kader sangat berperan dalam program kegiatan posyandu. Sikap dan kinerja kader yang tidak peduli dengan tujuan kegiatan posyandu dapat mempengaruhi kelangsungan kesehatan masyarakat sekitar terutama anak-anak penerus bangsa (Nugrahaeni dan Margawati, 2014).

Setiap kader Posyandu memiliki sikap yang berbeda dalam pelaksanaan Posyandu. Kondisi ini berdampak pada kualitas pelayanan Posyandu. Kader dalam melaksanakan pelayanan Posyandu hanya pada keinginan untuk mengisi waktu luang, selain itu untuk meningkatkan derajat kesehatan masyarakat dalam lingkungannya (Nugrahaeni dan Margawati, 2014). 
Kinerja adalah tingkat keberhasilan seseorang selama periode tertentu dalam melaksanakan tugas dibandingkan dengan berbagai kemungkinan, seperti standar hasil kerja, target yang telah ditentukan terlebih dahulu sesuai kesepakatan bersama. Kinerja yang banyak dilakukan kader yaitu memberikan informasi kepada masyarakat, mencatat penimbangan balita dan membuat laporan kegiatan. Kegiatan tersebut dilakukan karena sangat berhubungan dengan kelancaran kegiatan posyandu, dan tugas wajib kader untuk melaporkan hasil kegiatan kepada Puskesmas/bidan (Afni, 2015).

Penelitian Happinasari dan Suyandari (2016) menyatakan bahwa pengetahuan dan motivasi kader dapat mempengaruhi kinerja kader dalam pelaksanaan posyandu. Motivasi merupakan kondisi atau energi yang menggerakan kinerja kader untuk melaksanakan posyandu. Sikap mental kader yang baik akan memperkuat motivasi kerjanya untuk mencapai kinerja yang maksimal. Pengetahuan akan memberikan wawasan bagi seseorang dalam rangka mencari solusi atas permasalahan yang dihadapi, dengan demikian apabila pengetahuan yang baik akan berpengaruh dengan kinerja kader (Happinasari dan Suryandari, 2016).

Pengetahuan kader dapat ditingkatkan dengan adanya penggunaan media atau alat peraga. Media bisa membantu kader dalam melaksanakan tugasnya saat melakukan pemantauan status gizi balita di posyandu. Media lingkaran gizi (LINZI) dapat digunakan oleh kader untuk melihat status gizi balita dengan melihat Berat Badan per Umur dan kategori status gizi balita. Berat Badan per Umur digunakan sebagai skrining pertama di posyandu untuk mengetahui status gizi balita.

Tujuan penelitian ini adalah untuk mengetahui pengaruh edukasi media LINZI terhadap sikap dan kinerja kader dalam memantau status gizi balita di Kecamatan Blora Kabupaten Blora.

\section{Metode Penelitian}

Penelitian ini termasuk quasi experimental reaseach dengan rancangan Non Randomized Control Group Pretest and Posttest Design. Populasi yaitu seluruh kader di Kecamatan Blora Kabupaten Blora. Jumlah sampel 50 responden 25 kelompok perlakuan dan 25 kelompok control. Teknik sampling yang digunakan consecutive sampling. Variabel independen yaitu Media LINZI dan variabel dependen yaitu sikap kader dan kinerja kader. Instrumen variabel menggunakan kuesioner sikap dan kinerja kader yang sudah dilakukan uji validitas dan reliabilitas.

Pengumpulan data dibagi menjadi 2 kelompok yaitu kelompok perlakukan kader mendapatkan cara menggunakan media LINZI, sedangkan kelompok kontrol menggunakan media KMS. Kedua kelompok mendapatkan pre test sikap dan kinerja sebelum memulai tindakan. Pemberian edukasi diberikan selama 2 jam dimana responden diberikan penjelasan mengenai penggunakan media LINZI dengan menggunkan modul LINZI. Setelah 2 bulan kader menjalankan tugasnya baik menggunakan media linzi atau tidak dalam memantau status gizi balita maka dilakukan post test sikap dan kinerja kader.

Uji Analisis pada masing-masing variable terikat pre dan post test pada kedua kelompok menggunakan uji dependent $t$ test. Uji analisis yang dilakukan terhadap variabel bebas dan terikat dengan menggunakan 2 kelompok perlakuan berbeda, maka analisis pada penelitian ini variabel pre sikap dan kinerja kelompok kontrol dan perlakuan menggunakan uji Mann Whitney dan post sikap dan kinerja kontrol dan perlakuan menggunakan uji independent $t$ test. 


\section{Hasil dan Pembahasan}

\section{Karakteristik Responden}

Sampel penelitian ini adalah ibu kader sebanyak 50 responden yang memenuhi kriteria inklusi dan eksklusi. Karakteristik responden dapat dilihat pada tabel 1

Tabel 1

Karakteristik Responden

\begin{tabular}{|c|c|c|c|c|c|c|c|}
\hline & \multirow[t]{2}{*}{ Karakteristik } & \multicolumn{2}{|c|}{$\begin{array}{l}\text { Kelompok } \\
\text { Perlakuan }\end{array}$} & \multicolumn{2}{|c|}{$\begin{array}{l}\text { Kelompok } \\
\text { Kontrol }\end{array}$} & \multicolumn{2}{|c|}{ Total } \\
\hline & & $\mathrm{N}$ & $\%$ & $\mathrm{~N}$ & $\%$ & $\mathrm{~N}$ & $\%$ \\
\hline \multirow[t]{2}{*}{ Umur } & $\begin{array}{l}\text { Produktif } \\
\text { (15-65 th) }\end{array}$ & 25 & 50 & 25 & 50 & 50 & 100 \\
\hline & $\begin{array}{l}\text { Tidak Produktif } \\
\left(<14^{\text {th }} \text { dan }>66^{\text {th }}\right)\end{array}$ & 0 & 0 & 0 & 0 & 0 & 0 \\
\hline \multirow[t]{4}{*}{ Pendidikan } & SD & 1 & 2 & 7 & 14 & 8 & 16 \\
\hline & SMP & 3 & 6 & 10 & 22 & 13 & 28 \\
\hline & SMA & 18 & 36 & 8 & 14 & 26 & 50 \\
\hline & Sarjana & 3 & 6 & 0 & 0 & 3 & 6 \\
\hline \multirow[t]{3}{*}{ Pekerjaan } & IRT & 20 & 40 & 17 & 34 & 37 & 74 \\
\hline & Swasta & 2 & 4 & 4 & 8 & 6 & 12 \\
\hline & Petani & 3 & 6 & 4 & 8 & 7 & 14 \\
\hline \multirow[t]{2}{*}{ Masa Kerja } & Baru ( $\leq 3$ tahun) & 12 & 24 & 10 & 20 & 22 & 44 \\
\hline & Lama (>3 tahun) & 13 & 26 & 15 & 30 & 28 & 56 \\
\hline \multirow[t]{2}{*}{ Sikap Pre } & Positif & 10 & 20 & 10 & 20 & 20 & 40 \\
\hline & Negatif & 15 & 30 & 15 & 30 & 30 & 60 \\
\hline \multirow[t]{2}{*}{ Sikap Post } & Positif & 13 & 26 & 15 & 30 & 28 & 56 \\
\hline & Negatif & 12 & 24 & 10 & 20 & 22 & 44 \\
\hline \multirow[t]{2}{*}{ Kinerja Pre } & Baik & 13 & 26 & 13 & 26 & 26 & 52 \\
\hline & Kurang & 12 & 24 & 12 & 24 & 24 & 48 \\
\hline \multirow[t]{2}{*}{ Kinerja Post } & Baik & 13 & 26 & 13 & 26 & 26 & 52 \\
\hline & Kurang & 12 & 24 & 12 & 24 & 24 & 48 \\
\hline
\end{tabular}

Umur responden yaitu umur produktif $15-65$ tahun sebanyak $100 \%$ (50\% kelompok kontrol dan $50 \%$ kelompok perlakuan). Pendidikan terbanyak pada responden perlakuan SMA 36\% dan kontrol SMP 22\%. Pekerjaan rata-rata responden IRT(Ibu Rumah Tangga) sebanyak kelompok kontrol 34\% dan perlakuan $40 \%$. Masa Kerja responden ratarata sudah lama (> 3 tahun) kelompok kontrol $30 \%$ dan perlakuan $26 \%$. Sikap kader pada pre test kedua kelompok negatif (kelompok kontrol 30\% dan pelakuan $30 \%$ ). Sikap kader pada post test kedua kelompok positif (kelompok kontrol 30\% dan pelakuan 26\%). Kinerja kader dalam mentau pertumbuhan balita rata-rata sudah baik saat pre test maupun post test sebesar masing-masing $26 \%$ pada setiap kelompok.

Kelompok penduduk umur 0-14 tahun dianggap sebagai kelompok penduduk yang belum produktif secara ekonomis dan kelompok penduduk umur 64 tahun ke atas sebagai kelompok yang tidak lagi produktif. Kekuatan fisik seseorang untuk melakukan aktivitas sangat erat kaitannya dengan umur karena bila umur seseorang telah melewati masa produktif, maka semakin menurun kekuatan fisiknya sehingga produktivitasnya pun menurun. Dalam rentang usia produktif kader posyandu dapat lebih mengalokasikan waktunya untuk aktif dalam kegiatan posyandu (Suroyyo, 2017).

Seorang yang memiliki pendidikan formal yang tidak terlalu tinggi belum tentu tidak mampu dibandingkan dengan orang yang lebih tinggi pendidikan formalnya. Namun, faktor tingkat pendidikan turut menentukan mudah tidaknya menyerap dan memahami pengetahuan yang diperoleh. Adanya pekerjaan lain tentu akan membuat kader posyandu harus mampu mengalokasikan waktu sebaik mungkin untuk kegiatan posyandu dan pekerjaannya (Simanjuntak, 2012).

Semakin lama menjadi kader kesehatan diharapkan akan semakin banyak pengalaman serta 
pengetahuan sehingga diharapkan kader kesehatan dapat melayani masyarakat dengan baik dan lebih profesional. Kader yang memilki masa kerja lebih lama akan memiliki kedekatan yang lebih mendalam dengan masyarakat, karena kader sudah lebih banyak dikenal (Nurhayati dan Sistiarani, 2013). Lama menjadi kader dapat menilai kader berpengalaman dalam mengelola posyandu yang mengindikasikan adanya dukungan dari keluarga menjadi kader (Simanjuntak, 2012).

Sikap akan mendorong keinginan untuk bertindak dan berpersepsi sehingga akan membentuk perilaku yang berlanjut pada kinerja seseorang. Menurut Mangkunegara (2010), faktor yang mempengaruhi kinerja adalah faktor kemampuan dan motivasi. Sedangkan menurut Gibson dalam suwarto (2010), faktor yang mempengaruhi kinerja ada 3 variabel yaitu individu (kemampuan, ketrampilan, latar belakang dan demografis), organisasi (sumber daya, kepemimpinan, imbalan, struktur, desain pekerjaan) dan psikologis (persepsi, sikap, kepribadian, belajar, motivasi). Berdasarkan penelitian Putra dan Yuliatni (2016), kinerja kader yang kurang disebabkan karena adanya faktor umur < 30 tahun, pendidikan rendah, menjadi kader karena ditunjuk, belum mengikuti pelatihan dan pengetahuan yang dimiliki cukup.

\section{Penggunaan media LINZI terhadap Sikap Kader}

Tabel 2

Uji Beda pre post sikap pada masing-masing kelompok

\begin{tabular}{lccccc}
\hline & \multicolumn{2}{c}{ Pre } & \multicolumn{2}{c}{ Post } & P \\
\cline { 2 - 5 } & Mean & SD & Mean & SD & value \\
\hline Kontrol & 30.52 & 3.380 & 32.96 & 3.846 & 0.042 \\
Perlakuan & 31.08 & 3.662 & 33.08 & 3.616 & 0.04 \\
\hline
\end{tabular}

Pada tabel 2 menjelaskan sikap sebelum dan sesudah pada kelompok kontrol dan perlakuan. Uji normalitas dilakukan dengan hasil pada kelompok kontrol dan kelompok perlakuan yaitu distribusi data normal $(p>0.05)$. Hasil dari uji paired t test menunjukkan pada kelompok kontrol ada perbedaan antara pre test dan post test $\mathrm{p}=0.042$ $(\mathrm{p}<0.05)$ dan kelompok perlakuan ada perpedaan antara pre test dan post test $\mathrm{p}=0.04(\mathrm{P}<0.05)$.
Tabel 3

Pengaruh sikap antar kelompok

\begin{tabular}{llccl}
\hline \multicolumn{2}{c}{ Variabel } & N & Mean & P value \\
\hline Pre Sikap & Kontrol & 25 & 24.24 & 0.538 \\
& Perlakuan & 25 & 26.76 & \\
Post Sikap & Kontrol & 25 & 32.96 & 0.91 \\
& Perlakuan & 25 & 33.08 & \\
\hline
\end{tabular}

Tabel 3 menunjukkan perbedaan antara 2 kelompok kontrol dan perlakuan. Pada pre test sikap antara kedua kelompok menghasilkan distribusi data tidak normal $(\mathrm{p}<0.05)$. Uji yang digunakan adalah uji mann withney dengan hasil $\mathrm{p}=0.538(\mathrm{p}>0.05)$ artinya tidak ada perbedaan pre sikap antara kelompok perlakuan dan kontrol. Pada post test sikap uji normalitas menunjukkan data normal ( $\mathrm{p}>0.05)$. Uji yang digunakan uji independent $\mathrm{t}$ test dengan hasil $\mathrm{p}=0.91$ artinya tidak ada perbedaan antara kedua kelompok. Jika dilihat nilai mean ada perbedaan kelompok dengan media LINZI rata-rata skor sikap lebih besar 33.08 dibandingkan kontrol 32.96. Artinya antara media LINZI dan KMS mempunyai kemanfaatan yang sama dalam mendeteksi status gizi balita, dimana sikap kader akan berubah menjadi lebih baik ketika media LINZI bisa digunakan sebagai salah satu alternatif yang lebih menarik untuk para kader dalam melakukan skrining status gizi.

Secara teknis, tugas kader yang terkait dengan gizi adalah melakukan pendataan balita, melakukan penimbangan serta mencatatnya dalam Kartu Menuju Sehat (KMS), memberikan makanan tambahan, mendistribusikan vitamin A, melakukan penyuluhan gizi serta kunjungan ke rumah ibu yang menyusui dan ibu yang memiliki balita. Peran media/alat bantu dapat mempengaruhi sikap kader.

Penggunaan media KMS maupun media lain dapat digunakan untuk meningkatkan sikap kader karena adanya model pembelajaran baru akan meningkatkan rasa suka atau tertarik untuk pengetahuan para kader. Hal ini sesuai dengan penelitian Megawati, et al (2018) bahwa pengetahuan dan sikap kader posyandu meningkat setelah mendapatkan intervensi permainan simulasi. Hal ini menunjukan dengan adanya model pembelajaran atau intervensi yang lebih menyenangkan dapat meningkatkan sikap kader.

Penelitian Renate, Ilmi B, Arifin S, (2016) bahwa ada hubungan sikap positif, motivasi, penghargaan dan desain pekerjaan dengan kinerja kader di PTM Posbindu. Sikap positif kader adalah kesiapan dan kemauan untuk bertindak dan menciptakan kinerja yang baik sehingga pelaksanaan tugas kader dapat berjalan dengan 
lancar. Responden yang memiliki sikap positif akan menciptakan stimulus dalam bentuk kinerja yang baik. Sikap ini akan menjadi kekuatan pendorong bagi kader untuk berperilaku sesuai dengan sikapnya. Kondisi ini menyebabkan sikap memiliki hubungan yang kuat dengan kinerja yang baik.

\section{Penggunaan media LINZI terhadap Kinerja Kader}

Tabel 4

Uji Beda pre post kinerja pada masing-masing kelompok

\begin{tabular}{lccccc}
\hline & \multicolumn{2}{c}{ Pre } & \multicolumn{2}{c}{ Post } & \multirow{2}{*}{ P value } \\
\cline { 2 - 5 } & Mean & SD & Mean & SD & \\
\hline Kontrol & 39.28 & 4.088 & 42.96 & 3.116 & 0.001 \\
Perlakuan & 38.92 & 2.957 & 43.24 & 3.257 & 0.000 \\
\hline
\end{tabular}

Pada 4 menjelaskan kinerja sebelum dan sesudah pada kelompok kontrol dan perlakuan. Uji normalitas dilakukan dengan hasil pada kelompok kontrol dan kelompok perlakuan yaitu distribusi data normal $(\mathrm{p}>0.05)$. Hasil dari uji paired t test menunjukkan pada kelompok kontrol ada perbedaan antara sebelum dan sesudah $\mathrm{p}=0.001$ $(\mathrm{p}<0.05)$ dan kelompok perlakuan ada perpedaan antara sebelum dan sesudah $\mathrm{p}=0.000(\mathrm{P}<0.05)$.

Tabel 5

Uji Beda kinerja antar kelompok

\begin{tabular}{llrrl}
\hline \multicolumn{2}{c}{ Variabel } & N & Mean & P value \\
\hline Pre kinerja & Kontrol & 25 & 39.28 & 0.723 \\
& Perlakuan & 25 & 38.92 & \\
Post kinerja & Kontrol & 25 & 24.84 & 0.746 \\
& Perlakuan & 25 & 26.16 & \\
\hline
\end{tabular}

Tabel 5 menunjukkan perbedaan antara 2 kelompok kontrol dan perlakuan. Pada pre test kinerja antara kedua kelompok menghasilkan distribusi data normal ( $p>0.05)$. Uji yang digunakan adalah uji independent $t$ test dengan hasil $p=0.723(p>0.05)$ artinya tidak ada perbedaan pre kinerja antara kelompok perlakuan dan kontrol. Pada post test kinerja uji normalitas menunjukkan data tidak normal $(\mathrm{p}<0.05)$. Uji yang digunakan uji mann withney dengan hasil $\mathrm{p}=0.746$ artinya tidak ada perbedaan antara kedua kelompok. Namun jika dilihat nilai mean ada perbedaan antara kelompok kontrol dan perlakuan dimana kelompok dengan media LINZI rata-rata skor kinerja lebih besar 26.16 dibandingkan kontrol 24.84. Artinya antara media LINZI dan KMS mempunyai kemanfaatan yang sama dalam mendeteksi status gizi balita,
Kinerja kader dapat berubah menjadi lebih baik dengan menggunkan media LINZI karena dengan media yang mudah dan menarik dapat membuat kader semangat dalam mengerjakan tugasnya.

Berdasarkan penelitian Rowe, et al (2005) bahwa untuk meningkatkan kinerja dalam kesehatan diperlukan pengawasan dan audit umpan balik serta dilakukan intervensi yang lebih efektif serta menarik. Pemberian intervensi edukasi yang tepat dapat digunakan untuk mengubah sikap dan kinerja kader. Penelitian Hadiyanta, et al (2016) bahwa Pelatihan kader dengan metode bermain peran telah terbukti dapat meningkatkan pengetahuan peserta secara signifikan dan menjadi determinan keberhasilan meningkatkan kinerja kader dalam melakukan konseling. Penelitian Glenton, et al (2010) menyatakan bahwa seorang kader bisa melaksanakan program kesehatan dengan baik yaitu dengan memahami tujuan dan harapan yang akan dicapai serta dilakukan dengan kinerja tinggi.

\section{Simpulan}

Ada perbedaan pre post test sikap kader dalam memantau status gizi balita pada kelompok perlakuan dan kelompok kontrol. Ada perbedaan pre post test kinerja kader dalam memantau status gizi balita pada kelompok perlakuan dan kelompok control. Ada pengaruh edukasi media LINZI terhadap sikap kader dalam memantau status gizi balita di Kecamatan Blora Kabupaten Blora. Ada pengaruh edukasi media LINZI terhadap kinerja kader dalam memantau status gizi balita di Kecamatan Blora Kabupaten Blora. Bagi pembuat Kebijakan diharapkan hasil penelitian ini dapat digunakan sebagai referensi tambahan dalam menentukan media baru yang lebih efektif dan praktis untuk menentukan status gizi balita. Bagi institusi pelayanan kesehatan diharapkan dapat menambah informasi baru tentang media baru yaitu media LINZI dalam mengukur status gizi balita yang dapat membantu bidan dan petugas gizi dengan dibantu oleh kader dan bagi Masyarakat/Kader diharapkan dapat digunakan sebagai model baru yang dapat diterima masyarakat untuk memantau status gizi balita yang lebih praktis dengan menggunakan media LINZI.

\section{Daftar Pustaka}

Afni, R. (2015). Faktor-Faktor Yang Berhubungan Dengan Kinerja Kader Posyandu. Jurnal 
Ilmu Kebidanan Volume 3/Nomer 1/Maret 2015, 3(1), 1-6.

Dinas Kesehatan Provinsi Jawa Tengah. Buku profil kesehatan Provinsi Jawa tengah tahun 2015. Semarang: Dinkesprov Jateng; 2016.

Gibson, James, L. (2010). Organisasi, Perilaku, Struktur dan Proses . Jakarta: Erlangga.

Glenton, C., Scheel, I. B., Pradhan, S., Lewin, S., Hodgins, S., \& Shrestha, V. (2010). The Female Community Health Volunteer Programme In Nepal: Decision Makers' Perceptions Of Volunteerism, Payment And Other Incentives. Social Science \& Medicine, 70(12), 1920-1927.

Hadiyanta, T. H., Wahyudi Istiono, M. K., Pramantara, I. D. P., \& Sppd, K. G. (2016). Dampak Pelatihan Oleh Dokter Keluarga Terhadap Kinerja Kader Dalam Melakukan Konseling Di Posbindu Dusun Tahunan Kabupaten Gunungkidul (Doctoral Dissertation, Universitas Gadjah Mada).

Happinasari, O., \& Suryandari, A. E. (2016). Faktor-Faktor Yang Berhubungan Dengan Kinerja Kader Dalam Pelaksanaan Posyandu Di Kecamatan Purwokerto Selatan Kabupaten Banyumas. Jurnal Ilmu Kebidanan dan Kesehatan Akbid Bakti Utama Pati, 7.

Mangkunegara, A.P. 2010. Evaluasi Kinerja SDM. Bandung: Refika Aditama.

Megawati, M., Suriah, S., Ngatimin, R., \& Yani, A. (2018). Edukasi Tb Paru Pengetahuan Sikap Kader Posyandu Melalui Permainan Simulasi Monopoli. MPPKI (Media Publikasi Promosi Kesehatan Indonesia): The Indonesian Journal of Health Promotion, 1(1), 5-11.
Nugrahaeni, S. A., \& Margawati, A. (2014). Pengaruh Modul Terhadap Peningkatan Pengetahuan, Sikap Dan Praktek Kader Dalam Upaya Pemberian Asi Eksklusif. Gizi Indonesia, 37(1), 19-28.

Nurhayati, S., \& Sistiarani, C. (2013). Faktor Yang Mempengaruhi Peran Kader Dalam Penggunaan Buku Kesehatan Ibu Dan Anak. KEMAS: Jurnal Kesehatan Masyarakat, $8(2)$.

Putra, G. T. B., \& Yuliatni, P. C. D. Gambaran Pengetahuan Dan Kinerja Kader Posyandu Di Wilayah Kerja Upt Puskesmas Mengwi I Kabupaten Badung Pada Bulan Juli-Agustus 2015.

Renate, Ilmi B, Arifin S. 2016. Factors Associated With Performance Of POSBINDU PTM Cadres. EPRA International Journal Of Multidisciplinary Research (IJMR). 2:7:8193.

Rowe, A. K., De Savigny, D., Lanata, C. F., \& Victora, C. G. (2005). How Can We Achieve And Maintain High-Quality Performance Of Health Workers In Low-Resource Settings? The Lancet, 366(9490), 1026-1035.

Simanjuntak, M. (2012). Karakteristik Sosial Demografi Dan Faktor Pendorong Peningkatan Kinerja Kader Posyandu. JWEM (Jurnal Wira Ekonomi Mikroskil), 2(1).

Suroyya AN. 2017. Economic Analyses of household Fishing Gill Net on PPP Morodemak, Demak. Journal of Fisheries Resources Utilization Management and Technology Volume6, Nomor 4, Tahun 2017, Hlm 30 - 39. 